\title{
Determination of Heavy Metals in Sanitary Products of Women
}

\author{
Jeoung Hwa Shin ${ }^{\dagger}$ Kyu Keon Lee* - Myung-Hee Chung** \\ Korea Basic Science Institute, Environment \& Metabolomics Research Team \\ *Dept. of Internet Information \& Communication, Seojeong College University \\ **Dept. of Clothing Design, Bucheon University
}

Received January 22, 2009; Revised (March 5, 2009; March 30, 2009); Accepted April 1, 2009

\author{
여성용 위생용품의 유해중금속 분석 \\ 신정화 ${ }^{\dagger}$ 이규건* · 정명희** \\ 한국기초과학지원연구원, 환경대사체연구팀, *서정대학 인터넷정보과, **부천대학 의상디자인과 \\ 접수일(2009년 1월 22일), 수정일(1차 : 2009년 3월 5일, 완료일 : 2009년 3월 30일), 게재확정일(2009년 4월 1일)
}

\begin{abstract}
Endometriosis becomes the most common cause of pelvic pain and infertility women. The cause of endometriosis has ever been entirely proven. However, an increased use of commercial feminine hygiene products such as tampons and sanitary napkins was considered one of the major affect. Harmful substances in feminine hygiene products was analyzed and evaluated. Samples of commercial products obtained from Korea, Japan, America, Germany, and China were analyzed for six hazardous inorganic elements (chromium, cobalt, nickel, copper, cadmium and lead). In the extractable heavy metals of napkins, $\mathrm{Cr}, \mathrm{Ni}$ and $\mathrm{Cu}$ were found in all of the samples, while $\mathrm{Cd}$ was detected only in two samples. In the tampons, $\mathrm{Cr}, \mathrm{Ni}$ and $\mathrm{Cu}$ were found in all of the samples. The presence of $\mathrm{Co}$ and $\mathrm{Cd}$ was not detected in all samples The concentrations of extractable heavy metals in the tampons were lower than those in the sanitary napkins. The content of extractable heavy metals in the sanitary products was compared with the criteria of the 100 ÖKO TEX Standard. It was confirmed that the level of heavy metals in the sanitary products posed no serious risk to health, based on the human-ecological criteria defined by the 100 ÖKO TEX Standard.
\end{abstract}

Key words: Heavy metals, ICP-MS, Feminine hygiene products, Pulp, Acid digestion; 유해중금속, 플 라즈마 원자방출질량분석법, 여성용 위생용품, 펄프, 유도결합 습식분해법

\section{Introduction}

Recently, a continued increase in endometriosis has been observed which may be linked to exposure to environmental contaminants (Lamb \& Berg, 1985). This

\footnotetext{
Corresponding author

E-mail: jhshin01@kbsi.re.kr

This work was supported by the outstanding researchers program of the Korea Research Foundation(R042004-000-10204-0).
}

increasing prevalence of endometriosis is attributed to the use of disposable diapers in children and sanitary products in women of menstrual age (Hermansen \& Buches, 1988; Horstmann \& Mclachlan, 1995; Klasmeier \& Mclachlan, 1998). There are several hypotheses concerning the cause of endometriosis, the most popular of which is the premise that menstruation results in endometrial seeding of the peritoneal cavity. The possibility that tampon use might increase retrograde menstruation has been suggested; 
however, women with endometriosis do not appear to use tampons more than general population controls (Lamb \& Berg, 1985), and retrograde menstruation is believed to occur in most women, whether or not they use tampons. Although a number of factors, such as sexual activity, age, and socioeconomic status, have been associated with the risk of endometriosis (Houston et al., 1998), the concern about whether reproductive diseases in general, and endometriosis in particular, can be caused by tampons is focused on the presence of contaminants in feminine hygiene products.

Heavy metals become toxic when they are not metabolized by the body and accumulate in the soft tissues. Heavy metals may enter the human body through food, water, air, or absorption through the skin. Small amounts of these elements are common in our environment and diet and are actually necessary for good health, but large amounts of any of them may cause acute or chronic toxicity (poisoning). Heavy metal toxicity can result in damaged or reduced mental and central nervous function, lower energy levels, and damage to the blood composition, lungs, kidneys, liver, and other vital organs. Longterm exposure may result in slowly progressing physical, muscular, and neurological degenerative processes that mimic Alzheimer's disease, Parkinson's disease, muscular dystrophy, and multiple sclerosis. Allergies are not uncommon and repeated long-term contact with some metals or their compounds may even cause cancer.

Most studies have attached particular importance to the effects of hazardous substances transmitted to humans from the environment such as the soil, atmosphere, and water. Research into analytical methods, analytic technology and pretreatment has been focused on natural environments, rather than humans themselves. Thus, research on the noxiousness of feminine hygiene products has been rare. Under these circumstances, there has been concern about exposure to hazardous substances through the use of tampons and other feminine hygiene products. Feminine hygiene products including sanitary napkins and tampons are one of the most used and intimate products for the majority of women. Therefore, it is necessary to evaluate the level of toxic heavy metals in tampons and sanitary napkins, which come into contact with one of the most sensitive and important parts of a woman's body.

In this study, we concentrated our effort on determining for toxic heavy metals in different kinds of feminine hygiene products obtained from Korea, Japan, America, Germany, and China. It should be noted that there was no data available about the heavy metal contents in feminine hygiene products. We would like to express our profound concern about the exposure to heavy metals in clothing and the resulting environmental damage.

\section{Experimental}

\section{Materials and Apparatus}

Eighteen different kinds of feminine hygiene products for women manufactured in Korea, Japan, America, Germany, and China were used and the levels of heavy metals within them were determined and quantified. These feminine hygiene products can be classified into two types, sanitary napkins and tampons. The collected sanitary napkins were as follows: 3 kinds from Korea (K1, K2, K3), 2 kinds from Japan (J1, J2), 3 kinds from the USA (U1, U2, U3), 3 kinds from Germany (G1, G2, G3) and 2 kinds from China (C1, C2). The tampons that were selected were as follows: one kind from Korea (TK), 2 kinds from Japan (TJ1, TJ2), and 2 kinds from the USA (TU1, TU2). Each brands of Sanitary napkins and tampons are used generally (Shin et al., 2007).

The acids used in this study, including sulfuric acid and nitric acid, were obtained from the E. Merck Company (Germany). Hot plate heating digestion was employed. Inductively coupled plasma mass (spectrometry) (ICP-MS, Elan 6100 DRC, Perkin Elmer) was used for analyzing six heavy metals, i.e. $\mathrm{Cr}$, $\mathrm{Co}$, $\mathrm{Ni}, \mathrm{Cu}, \mathrm{Cd}$, and $\mathrm{Pb}$.

For the purpose of comparison with the 100 ÖKO TEX Standard (Colbert, 1994), the content of heavy metals in sanitary samples was determined for the extracts by artificial acid sweat, according to the standard PN-EN-ISO 105-E04. Therefore, 0.5g Lhistidine monohydrochloride, $5.0 \mathrm{~g} \mathrm{NaCl}$ and $2.2 \mathrm{~g}$ 
disodium hydrogen orthophosphate were dissolved in water. The solution was brought to $\mathrm{pH} 5.5$ with $0.1 \mathrm{M} \mathrm{NaOH}$. A such solution was prepared daily.

\section{Extractable Metal Levels}

In order to determine extractable metal levels, the sanitary samples were extracted with artificial acidic sweat solution. For this purpose $0.5 \mathrm{~g}$ of each cloth was weighed and transferred to a $25 \mathrm{ml}$ beaker. Then $10 \mathrm{ml}$ of artificial sweat solution was added. The solution was heated at $37^{\circ} \mathrm{C}$ for 24 hours on a magnetic stirrer. Then the samples were removed from the solutions. The volume of the final solution was made up to $10 \mathrm{ml}$ in volumetric flask.

\section{Conventional Hot Plate digestion method}

Conventional hot plate digestion was performed with an acid mixture using Teflon beakers. A precisely weighed samples $(0.5-1 \mathrm{~g})$ put into the beakers, to which a pre-mixed acid solution was added. The samples were heated on a hot plate (instrument set temperature: $150^{\circ} \mathrm{C}$ ) to dissolve the samples. Afterwards, the sample was cooled below $70^{\circ} \mathrm{C}, 6 \mathrm{ml}$ of concentrated $\mathrm{HNO}_{3}$ was added and the samples were refluxed at $150^{\circ} \mathrm{C}$. Subsequently, the samples were evaporated without boiling. After cooling to room temperature, the samples were diluted.

\section{Data analyses}

The values were expressed as means of three measurements. Comparisons of sanitary products were made employing one way ANOVA using Window SAS version 12.0. When significant interaction was found, Sheffe's Test was performed.

\section{Results and Discussion}

\section{Determination of Heavy Metal Content in Sanitary Napkins}

<Table 1> shows the results of the tests for the presence of heavy metals in the women's sanitary napkins. The content of heavy metals was determined for $\mathrm{Cr}, \mathrm{Co}, \mathrm{Ni}, \mathrm{Cu}, \mathrm{Cd}$ and $\mathrm{Pb}$ and $\mathrm{F}$-values were presented in this table.

The heavy metal content was determined for the 3 Korean, 2 Japanese, 3 American, 3 German and 2 Chinese samples.

The highest concentration of heavy metals in the tested samples was detected for $\mathrm{Cu}$. The concentrations of heavy metals in $\mathrm{C} 1$ from China and $\mathrm{U} 3$ from

Table 1. Heavy metal concentrations in the napkins produced in Korea, Japan, America, Germany, and China (unit: ppm)

\begin{tabular}{|c|c|c|c|c|c|c|}
\hline & $\mathrm{Cr}$ & $\mathrm{Co}$ & $\mathrm{Ni}$ & $\mathrm{Cu}$ & $\mathrm{Cd}$ & $\mathrm{Pb}$ \\
\hline K1 & 0.257 & 0.751 & 0.074 & 1.548 & N.D & 0.059 \\
\hline K2 & 0.251 & 0.012 & 0.075 & 1.842 & N.D & 0.040 \\
\hline K3 & 0.303 & 0.069 & 0.285 & 2.813 & N.D & 0.105 \\
\hline $\mathrm{J} 1$ & 0.106 & 0.794 & 0.050 & 1.869 & N.D & 0.190 \\
\hline $\mathrm{J} 2$ & 0.155 & 0.260 & N.D & 0.930 & N.D & 0.030 \\
\hline U1 & 0.307 & N.D & 0.030 & 0.432 & N.D & N.D \\
\hline $\mathrm{U} 2$ & 0.388 & 0.173 & 0.076 & 2.527 & N.D & 0.027 \\
\hline U3 & 0.278 & N.D & 0.021 & 3.594 & N.D & 0.042 \\
\hline G1 & 0.242 & N.D & 0.067 & 0.229 & N.D & 0.018 \\
\hline G2 & 0.204 & N.D & 0.044 & 0.373 & N.D & 0.070 \\
\hline G3 & 0.303 & N.D & 0.051 & 0.095 & N.D & 0.034 \\
\hline $\mathrm{C} 1$ & 0.530 & 0.110 & 0.890 & 4.901 & 0.020 & 0.308 \\
\hline $\mathrm{C} 2$ & 0.465 & 0.010 & 0.160 & 1.294 & 0.023 & 0.080 \\
\hline$F$ & $3.02^{+}$ & $6.25^{* *}$ & $18.45^{* * * *}$ & $9.45^{* * * *}$ & 0.92 & 0.65 \\
\hline
\end{tabular}

${ }^{+} p<.05, * * p<.005, * * * p<.001$

K: Korea, J: Japan, U: America, G: Germany, C: China, N.D: not detected 
America $(p<.001)$ were significantly higher than other samples.

$100 \%$ of the samples also contained trace quantities of $\mathrm{Cu}$ and $\mathrm{Cr}$. $92.3 \%$ of the samples contained trace quantities of $\mathrm{Ni}$ and $\mathrm{Pb} .61 .5 \%$ of the samples contained trace quantities of Co. $15.4 \%$ of the samples contained trace quantities of $\mathrm{Cd}$.

The trace quantity of chromium discovered in all of the samples remains on the level of tenth-fractions of ppm, with deviations ranging from 0.106 to 0.530 .

Trace amounts of $\mathrm{Pb}$ were encountered in the majority of the samples $(92 \%)$, within the range of $0.018 \mathrm{ppm}$ for $\mathrm{G} 1$ to $0.308 \mathrm{ppm}$ for $\mathrm{C} 1$. These results indicate that $\mathrm{Pb}$ was present at an almost equal level throughout the samples, in most cases corresponding to hundredth-fractions of ppm. No lead was found in one of the samples from America.

A trace quantity of cobalt was detected in $61.5 \%$ of the samples at the level of hundredth- or thousandthfractions, or at the level of $0.1 \mathrm{ppm}$. K1 and $\mathrm{J} 1$ ( $p<$ $.005)$ were significantly higher than other samples.

The presence of cadmium was detected the samples from China, with a uniform content of hundredth-fractions of ppm.

A considerable dispersion of results was obtained in the case of Ni. J2 was the only sample showing no trace of $\mathrm{Ni}$. The level of Ni corresponds to hundredthfractions of ppm in $76.9 \%$ (10 samples) and tenthfractions of ppm in $23.1 \%$ ( 3 samples) of the samples.

These results show that the regulation of textile products in European countries is stricter and more effective than that in the other countries. Also, the regulation of the environment, including textile products, in China is still deficient.

The content of heavy metals in sanitary napkins was higher than that in disposable baby diapers (Shin et al., 2004).

The regulations concerning infant products are stricter than those regarding adult products. The concentrations of heavy metals in the infant products were between 1 to 5 times lower than those in the adult products.

In previous studies, most of the wood pulp, paper and textiles (Edward et al., 2004) were found to have similar heavy metal concentrations and profiles on comparing the sanitary napkins to tampons and disposable baby diapers.

The concentrations of the heavy metals in the women's sanitary napkins found in artificial sweat extract are given in <Table 2>.

$\mathrm{Cr}, \mathrm{Ni}$ and $\mathrm{Cu}$ were present in all of the samples at levels of 0.5-29.3 ppb for $\mathrm{Cr}, 2.9-14.7 \mathrm{ppb}$ for $\mathrm{Ni}$ and

Table 2. Concentrations of extractable heavy metals in the napkins produced in Korea, Japan, America, Germany, and China

(unit: ppb)

\begin{tabular}{|c|c|c|c|c|c|c|}
\hline & $\mathrm{Cr}$ & Co & $\mathrm{Ni}$ & $\mathrm{Cu}$ & $\mathrm{Cd}$ & $\mathrm{Pb}$ \\
\hline K1 & 0.532 & 1.319 & 14.738 & 20.668 & 0.745 & 1.080 \\
\hline $\mathrm{K} 2$ & 2.868 & N.D & 5.328 & 7.230 & N.D & 5.022 \\
\hline K3 & 1.177 & N.D & 3.691 & 3.059 & N.D & N.D \\
\hline $\mathrm{J} 1$ & 7.304 & 1.028 & 5.091 & 15.167 & N.D & 4.786 \\
\hline $\mathrm{J} 2$ & 2.701 & N.D & 3.305 & 8.577 & N.D & 0.819 \\
\hline U1 & 7.147 & N.D & 5.207 & 12.276 & N.D & 3.379 \\
\hline $\mathrm{U} 2$ & 6.486 & 1.201 & 7.043 & 11.628 & N.D & 3.800 \\
\hline U3 & 1.614 & 0.616 & 10.740 & 22.943 & 1.350 & 4.770 \\
\hline G1 & 5.247 & N.D & 4.234 & 13.937 & N.D & 3.883 \\
\hline $\mathrm{G} 2$ & 2.934 & 1.277 & 2.939 & 6.661 & N.D & N.D \\
\hline G3 & 1.780 & N.D & 3.246 & 8.390 & N.D & N.D \\
\hline $\mathrm{C} 1$ & 29.286 & N.D & 11.797 & 18.427 & N.D & 1.080 \\
\hline $\mathrm{C} 2$ & 1.649 & N.D & 3.237 & 51.866 & N.D & 2.478 \\
\hline $\mathrm{F}$ & 1.63 & $3.31^{+}$ & $4.50 *$ & $12.95^{* * *}$ & 0.90 & $3.16^{+}$ \\
\hline
\end{tabular}

${ }^{+} p<.05, * p<.01, * * * p<.001$

K: Korea, J: Japan, U: America, G: Germany, C: China, N.D: not detected 
3.1-51.9 ppb for $\mathrm{Cu}$. The highest concentration was significantly detected for $\mathrm{Cu}$ in $\mathrm{C} 2(p<.001)$ from China. While Cd wase detected only in two samples, although at a concentration considerably lower than those of $\mathrm{Cr}$, $\mathrm{Ni}$ and $\mathrm{Cu}$.

The content in tested samples did not exceed the permissible level, according to the criteria of the 100 ÖKO TEX Standard (Table 3).

\section{Determination of Heavy Metal Content in Tampons}

$<$ Table 4> illustrates the concentrations of heavy metals in the women's tampons and F-values were presented in this table.

Trace quantities of $\mathrm{Ni}, \mathrm{Cu}$, and $\mathrm{Pb}$ were detected in all of the samples, at the level of hundredth-fractions for $\mathrm{Ni}$, tenth- fractions or $1 \mathrm{ppm}$ for $\mathrm{Cu}$, and tenth- or hundredth-fractions for $\mathrm{Pb}$.

Table 3. Limit values of Oeko-Tex Standard 100

\begin{tabular}{c|c|c|c}
\multicolumn{4}{|c}{ Oeko-Tex Standard 100 } \\
\hline \hline \multirow{2}{*}{ metals } & \multicolumn{4}{|c}{ (unit: ppm) } \\
\cline { 2 - 4 } & $\mathrm{A}$ & $\mathrm{B}$ & $\mathrm{C}$ \\
\hline $\mathrm{Sb}$ (antimony) & 30.0 & 30.0 & 30.0 \\
\hline $\mathrm{As}$ (arsenic) & 0.2 & 1.0 & 1.0 \\
\hline $\mathrm{Pb}($ lead $)$ & 0.2 & 1.0 & 1.0 \\
\hline $\mathrm{Cd}($ cadmium) & 0.1 & 0.1 & 0.1 \\
\hline $\mathrm{Cr}($ chromium $)$ & 1.0 & 2.0 & 2.0 \\
\hline $\mathrm{Cr}(\mathrm{VI})$ & \multicolumn{3}{|c}{ Under detection limit } \\
\hline $\mathrm{Co}($ cobalt $)$ & 1.0 & 4.0 & 4.0 \\
\hline $\mathrm{Cu}$ (copper) & 25.0 & 50.0 & 50.0 \\
\hline $\mathrm{Ni}$ (nickel) & 1.0 & 4.0 & 4.0 \\
\hline $\mathrm{A}: \mathrm{Baby}, \mathrm{B}: \mathrm{in}$
\end{tabular}

A: Baby, B: in direct contact with skin,

C: with no direct contact with skin
Similar trace quantities of $\mathrm{Co}$ and $\mathrm{Cd}$ were observed, ranging from N.D. to the level of hundredth-fractions.

Trace quantities of $\mathrm{Cr}$ were detected ranging from N.D. to the level of tenth- or hundredth-fractions.

The heavy metal contents in the tampons were lower than those in the sanitary napkins with the exception of $\mathrm{Pb}$.

Moreover, the results obtained from the disposable diapers and tampons for women show that the concentration of each heavy metal species in the disposable tampons for women was higher than that in the disposable diapers.

The concentrations of the heavy metals in women's tampons found in artificial sweat extract are given in <Table 5>. Cr, $\mathrm{Ni}$ and $\mathrm{Cu}$ were found in all of the samples. The highest concentration of heavy metals in the tested samples was detected for $\mathrm{Cu}$. The concentrations of heavy metals in the tampons were lower than those in the sanitary napkins. The content in tested samples did not exceed the permissible level, according to the criteria of the 100 ÖKO TEX Standard (Table 3).

\section{Conclusions}

Tests for the presence of heavy metals $(\mathrm{Cd}, \mathrm{Co}, \mathrm{Cr}$, $\mathrm{Cu}, \mathrm{Ni}$ and $\mathrm{Pb}$ ) harmful to human health were carried out for 23 feminine hygiene products.

In the concentration of heavy metals in sanitary napkins, $\mathrm{Cr}, \mathrm{Cu}$, and $\mathrm{Pb}$ were found in all of the tested samples at levels of 0.1-0.5 ppm for $\mathrm{Cr}, 0.1-4.9$ ppm for $\mathrm{Cu}$, and 0.02-0.3 ppm for $\mathrm{Pb}$. The presence of $\mathrm{Cd}$ was only detected in the samples from China in trace quantities considerably lower than $0.1 \mathrm{ppm}$.

Table 4. Heavy metal concentrations in the tampons produced in Korea, Japan, and America (unit: ppm)

\begin{tabular}{c|c|c|c|c|c|c}
\hline \hline & $\mathrm{Cr}$ & $\mathrm{Co}$ & $\mathrm{Ni}$ & $\mathrm{Cu}$ & $\mathrm{Cd}$ & $\mathrm{Pb}$ \\
\hline $\mathrm{TK} 1$ & 0.028 & 0.027 & 0.089 & 3.509 & 0.032 & 0.872 \\
\hline $\mathrm{TJ} 1$ & $\mathrm{~N} . \mathrm{D}$ & 0.032 & 0.056 & 0.288 & $\mathrm{~N} . \mathrm{D}$ & 0.589 \\
\hline $\mathrm{TJ} 2$ & 0.049 & 0.046 & 0.084 & 0.294 & $\mathrm{~N} . \mathrm{D}$ & 0.277 \\
\hline $\mathrm{TU} 1$ & 0.120 & N.D & 0.094 & 2.296 & 0.027 & 0.096 \\
\hline TU2 & 0.071 & N.D & 0.074 & 0.384 & N.D & 0.083 \\
\hline$F$ & 2.73 & $131.83^{* * *}$ & $10.64^{+}$ & $135.47 * * *$ & $36.20^{* * *}$ & $588.10^{* * *}$ \\
\hline${ }^{+} p<.05, * * * p<.001$ & & &
\end{tabular}

K: Korea, J: Japan, U: America, N.D: not detected 
Table 5. Concentrations of extractable heavy metals in the tampons produced in Korea, Japan, and America (unit: ppb)

\begin{tabular}{c|c|c|c|c|c|c}
\hline \hline & $\mathrm{Cr}$ & $\mathrm{Co}$ & $\mathrm{Ni}$ & $\mathrm{Cu}$ & $\mathrm{Cd}$ & $\mathrm{Pb}$ \\
\hline TK1 & 2.010 & 0.468 & 1.972 & 9.337 & 0.133 & N.D \\
\hline TJ1 & 1.996 & N.D & 1.573 & 3.748 & N.D & 0.223 \\
\hline TJ2 & 1.179 & N.D & 3.783 & 4.002 & N.D & 0.134 \\
\hline TU1 & 2.709 & 0.106 & 3.216 & 2.639 & 0.157 & N.D \\
\hline TU2 & 3.945 & 0.170 & 7.073 & 8.016 & 0.174 & 0.607 \\
\hline F & $5.85^{+}$ & $35.64 * * *$ & 1.16 & 4.81 & 1.15 & 0.83 \\
\hline
\end{tabular}

${ }^{+} p<.05, * * * p<.001$

K: Korea, J: Japan, U: America, N.D: not detected

Co and As appeared in several more samples, in quantities also below $0.1 \mathrm{ppm}$.

In the tampons, $\mathrm{Ni}, \mathrm{Cu}$, and $\mathrm{Pb}$ were found in all of the tested samples. The presence of $\mathrm{Co}$ and $\mathrm{Cd}$ was only detected in a few samples in trace quantities considerably lower than $0.1 \mathrm{ppm}$. Cr appeared in several more samples, in quantities also below $1 \mathrm{ppm}$.

The heavy metal contents in the tampons were lower than those in the sanitary napkins except for $\mathrm{Pb}$.

In the concentrations of heavy metals and extractable heavy metals in sanitary products, $\mathrm{Cu}$ was higher than other samples.

The concentration of extractable heavy metals in napkins and tampons samples did not exceed the permissible level, according to the criteria of the 100 ÖKO TEX Standard. It was confirmed that the level of heavy metals in the sanitary products posed no serious risk to health, based on the human-ecological criteria defined by the 100 ÖKO TEX Standard.

The purpose of this study was the analysis of inorganic compounds (heavy metals) in feminine hygiene products. It should be noted here that there was no data available about the heavy metal contents in feminine hygiene products. We would like to express our profound concern about the exposure to heavy metals in clothing and the resulting environmental damage.

\section{References}

Edward, R., Teresa, Ś., Ewa, L., Jadwiga, A., Małgorzata S., Tadeusz, P., \& Stanisław, S. (2004). Changes in hazardous substances in cotton after mechanical and chemical treatments of textiles. FIBRES \& TEXTILES in Eastern Europe, 12(2), 67-73.

Colbert, B. (1994). ÖKO TEX Standard. International Conference Ekotextil 94, Sulejow, Poland.

Hermansen, M. C., \& Buches, M. (1988). Urine output determination from superabsorbent and regular diapers under radiant heat. Pediatrics, 81(3), 428-431.

Horstmann, M., \& Mclachlan, M. S. (1995). Results of an initial survey of polychlorinated dibenzo-p-dioxins (PCDD) and dibenzofurans (PCDF) in textiles. Chemosphere, 31(11), 2579-2589.

Houston, D., Noller, K., Melton, J. I., \& Selwyn, B. (1998). The epidemiology of pelvic endometriosis. Clin Obstet Gynecol, 31(4), 787-800.

Klasmeier, J., \& Mclachlan, M. S. (1998). PCDD/Fs in textiles - Part 1: A screening method for detection of octachlorodibenzo-p-dioxin and octachlorodibenzofuran. Chemosphere, 36(7), 1627-1635.

Lamb, K., \& Berg, N. (1985). Tampon use in women with endometriosis. J. Community Health, 10(4), 215-225.

Shin, J. H., Chung, M. H., Park, M., \& Ahn, Y. G. (2007). A comparison study of the views and actual use of women's sanitary products in Korea and Japan. $J$. Korean. Soc. Living. Environ. Sys., 14(2), 110-116.

Shin, J. H., Yoon, H., Park, M., \& Ahn, Y. (2004). Hazardous substance analysis of disposable diaper for infant. Journal of the Korean Society of Clothing and Textiles, 28(1), 165-171. 


\section{요 약}

각국의 여성용 위생용품의 유해중금속을 비교 평가하기 위하여, 일회용 생리대는 한국 3 개사, 일본 2 개 사, 미국 3 개사, 독일 3 개사, 중국 2 개사의 시료와, 여성용 일회용 탐폰은 한국 1 개사, 일본 2 개사, 미국 2 개 사 시료를 대상으로 $\mathrm{Cr}, \mathrm{Co}, \mathrm{Ni}, \mathrm{Cu}, \mathrm{Cd}, \mathrm{Pb}$ 의 유해중금속 분석을 행하였다. 여성용 일회용 생리대의 용출 실험에서는 $\mathrm{Cr}, \mathrm{Ni}, \mathrm{Cu}$ 가 모든 시료에서 검출 되었다. 또한 여성용 일회용 탐폰의 용출실험에서 $\mathrm{Cr}, \mathrm{Ni}$, $\mathrm{Cu}$ 가 모든 시료에서 검출 되었다. 여성용 일회용 탐폰의 용출실험의 결과는 생리대의 결과값보다 낮은 농도롤 나타내었다. 본 연구에서 분석한 각국 여성용 일회용 위생용품의 유해중금속의 분석값은 OekoTex Standard 100 의 규제치와의 비교에서 규제치 이하로 인체유해성은 없는 것으로 판단되어진다. 